\title{
Migrant remittance behavior in Uganda: A household analysis
}

\author{
John .A. Mushomi, James. P.M. Ntozi \& Gideon Rutaremwa \\ Department of Population Studies, Makerere University, Kampala \\ Uganda \\ jmushomi@gmail.com
}

\begin{abstract}
Background: World over, development of nations is directly linked to migration since one in seven people in the world is a migrant and a quarter of them, international migrants (Ratha, 2005). The economic importance of international migrants has been demonstrated by international remittances that are sent to families in the migrants' home countries. According to World Bank, 2015, remittance flows to developing countries were expected to reach $\$ 414$ billion in 2013 (up 6.3 percent over 20I2), and $\$ 540$ billion by 2016 . Worldwide, remittance flows may reach $\$ 550$ billion in 2013 and over $\$ 700$ billion by 2016 . Despite an increased interest in the role of international remittances at the international level, sparse information that exists in Uganda reveals that little or no attention has been put on examining whether remittances are invested in development or non- development ventures at household level (Wamala, 2010). This research gap warrants a need for studies on understanding the role of international remittances. Exploring the role of remittances and how it offers ingredients to enhance the development potential for citizens is important. This will be a contribution to the development in Uganda given that during the global financial crisis remittances proved resilient by falling with a minimal margin compared to the foreign direct investment; private debt and portfolio equity flows.
\end{abstract}

Data Sources: Data from the survey on personal transfers by Ugandans living abroad during the year 2010 is used. This survey was the fourth in a series of annual surveys jointly conducted by Bank of Uganda and the Uganda Bureau of Statistics.

Methods: Complementary log-log regression model was used because of the small numbers of households in the categories of interest (asymmetrically distributed). Survey weights were applied to data in order to account for the complex survey design including clustering and stratification.

Results: Remittance receipt status was determined by region of the household, number of rooms in the house, household main source of lighting fuel. Using remittances for development was determined by sex of the household head, household regional location, house ownership status sex, marital status and senders' residence.

Conclusion: Results show that a household that had a member abroad also had higher chances of receiving remittances compared to the household with no member abroad. Results on the contrary found household and household head characteristics significantly associated with remittance receipt status of a household. Use of international remittances for development of households was significantly determined by sex of the household head, regional location of the household, house ownership status and number of rooms in the house. It is therefore recommended that government should leverage migration opportunities for women and also expand migration opportunities across all regions of the country since it augments development for households with migrants

Keywords: Household, Migration, International remittances, Uganda.

\section{Introduction}

World over, development of nations is directly linked to migration since one in seven people in the world is a migrant and a quarter of them, international migrants (Ratha, 2005). The economic importance of international migrants has been demonstrated by international remittances that are sent to families in the migrants' home countries. International migration is one of the most important factors affecting economic relations between developed and developing countries in the 2 Ist century. At the start http://aps.journals.ac.za of the century, it was estimated that about 175 million people, roughly $3 \%$ of the world population, lived and worked outside the country of their birth (United Nations, 2002).

Where as the study from Omondi e.t al (2005) demonstrated that there is an inverse relationship between migration and the number of children ever born, international remittances sent by these migrant workers especially female workers to their households back home have a large and profound 
impact on the developing world.Therefore the contribution of the female folk ought to be looked at beyond children they give birth to but within a wider development context. International remittances sent home by migrant workers represent the second most important source of external funding for developing countries. Official international remittances now total $\$ 75$ billion per year and are about twice as large as the level of official aid-related inflows to developing countries (World Bank, 2004).

Despite the ever-increasing size of official international remittances, relatively little attention has been paid to examining the economic impact of these transfers on households in developing countries. A host of key policy questions thus remain unanswered: What kind of migrants remit? How do international remittances affect the welfare and poverty status of households in migrant sending countries? And how do remittance-receiving households use their remittance earnings? Exploring the role of remittances and how it offers ingredients to enhance the development potential for citizens is important. This presents the potential of remittances to trigger development especially in low-income countries. This paper is investigates the factors associated with use of international remittances at household level in Uganda, studies the predictors of household receiving remittances and, factors associated with use of remittances for development by remittance receiving households are investigated.

\section{Theoretical framework and review of literature}

Philosophically, the ideology behind the remittanceoptimistic developmentalist school argues that international remittances have potential of enhancing the development process in both the developed and developing countries (Gamlen, A. 20I4).International remittances have a likelihood of increasing investment and subsequently stimulating development and modernization of the underdeveloped economies. This could happen through the North- South transfer of investment capital and accelerates the exposure of labourexporting communities to liberal, rational and democratic ideas, modern knowledge and education. This ideology argues that international remittances normally contribute positively to the elimination of production and investment constraints, raising the average household's incomes in real terms and lessening the balance of payment problems of the developing countriesThey further argue that international remittances contribute to narrowing of the trade gap and it facilitates debt servicing for countries.

The developmentalist school also argues that migrants, especially permanent emigrants, sometimes use part of their earnings to finance critical development projects in their native countries. They further contend that the emergence of remittances on the global scene has encouraged international migration to advanced economies resulting into increasing large-scale production due to cheap labour from developing countries. This reduces the average cost of production in the industrialized countries. Therefore, international remittances possess a twosided positive impact on the global economy.

This ideology is supported by the empirical works of Lucas, (2004), Lowell, (2002), Stark et al.(1997), Massey,(1998), Bhagwati,( 2003), Ammassari, (2003) and Stahl, (1986) which suggest that developing countries stand to gain from the brain drain by way of remittances from migrant nationals who would have otherwise been unemployed or lowly paid in their poor countries of origin .In support of the remittance- optimistic development scholars, World Bank, (2007), concluded from an empirical study that remittances generally reduce poverty and can help redistribute income in developing countries. Specifically, Gupta et al.,(2007) established that international remittances have contributed to poverty reduction and financial development in Sub-Saharan Africa. Mora and Taylor, (2004) confirmed that in Mexico both internal and international remittances were found to reduce rural poverty but international remittances reduced poverty much more.

It was also observed that educational attainment increases the likelihood of internal migration to nonfarm engagements, but this does not have any effect on international migration. Edwards and Ureta, (2003) also found that in Guatemala both internal and international remittances payments reduced the level, depth and severity of poverty. The poorest 10\% receive between $50 \%$ and $60 \%$ of the total household income from remittances. Households benefiting from remittances were more likely to spend higher proportions of their incomes on food and other consumer durables. Remittance receiving households spent $58 \%$ more on education than nonreceiving households.

International remittance receiving households often tend to have a higher propensity to invest than non-remittance - receiving households do. Results from some empirical studies on developing countries have concluded that international remittances do not necessarily lead to passive dependency as suggested by the pessimistic school of thought, but may rather lead to increased economic activities and wealth (De Haas, , 2003). The pessimistic school of thought in a counter argument, which mainly claim that the quest for international remittances leads to international migration which drains native developing countries of the highly skilled and trained skilled labour and capital 
by crowding out domestic production of tradable goods in the brain drained underdeveloped economies. They posited that the net effect of international migration and remittances is only to sustain and or even reinforce the problems of underdevelopment rather than promoting sustainable development. This implies that advanced economies stand to gain more in international migration and remittances through cheap labour, high taxation on migrant earnings and to some extent from commissions paid by migrants when transferring remittances to native countries. Accordingly, low wages paid to migrants in the developed countries are not sufficient to benefit developing countries substantially in narrowing the development gap between the advanced and the developing economies.

Based on this conception, remittance - pessimistic school believes that international remittances, apart from deepening foreign dependent mentality of developing countries, may promote higher inequality among households and macroeconomic instability in form of inflation through excess demand of consumables relative to deficit in domestic production capacity of developing countries (Stark 1982,Lipton, 1980, Ahlburg, 1995 \& Rubenstein, 1992). It is further argued that there is a high tendency that remittances would easily be spent on conspicuous consumption and consumptive or nonproductive investments such as real estate acquisition and for that matter are rarely invested in productive enterprises.Furthermore, in support of the remittance- pessimistic paradigm, other studies have highlighted the impact of migrant remittances on the labour market of receiving countries. It is claimed in the literature that remittances could create a disincentive to work and lead to a decline in labour participation for members of receiving households due to the preference for leisure consumption. Frankhauser, (1992) supports this claim by suggesting that the higher income component of remittances could lead to lower labour force participation of the remaining household members.

International migration has been viewed as robbing poor countries of brains through brain drain. However, the opportunities created by the global market for skilled labor may give hopes for migrants to get profitable fallout. This usually leads to migrants sending money back to their households.Munshi (2003) identified a set of determinants of willingness to send which included; possession of children, networks based on attachments to the left behind and marital status. The micro - economic determinants operate mostly at household level. These factors are: the ratio of female in population of host country, years since worker migrated, household income level, employment of other household members and marital status of migrant. Other micro economic factors include: years of education of migrant and occupation status of migrants (Aydaset al.2004).In the past, researchers have often taken a rather pessimistic view of how remittances are spent or used and the impact of these monies on development. For example, a recent review of the literature by Chami, et al, (2005) reported that a "significant proportion, and often the majority," of remittances are spent on consumption; that a smaller part of remittance funds goes into saving or investment; and the ways in which remittances are typically saved or invested - in housing, land and social functions - are "not necessarily productive" to the economy as a whole.In a study using a 1988 survey of 1526 Egyptian migrants who had worked abroad and returned home, an examination of how international migration and remittances affect the probability that a migrant will invest in entrepreneurial businesses hence becoming an entrepreneur upon returning home found that time spent abroad and total amount of money saved abroad had a positive and significant effect on the likelihood of a return migrant becoming an entrepreneur (McCormick \&Wahba, 200I).Generally, a small percentage of remittances are used for savings and "productive investments", i.e. for activities with multiplier effects in terms of income and employment creation (Brink, 1991 and Eurostat,2000). Waddington, (2003) notes that mobile livelihoods or livelihoods involving the geographic dispersal of household members maybe poverty reducing and involve the redistribution of resources not only across space but also within a family or household. The review of literature has found that works on remittances and development is still inconclusive especially on how remittances lead to economic growth, thus it can only be referred to as a proxy for economic growth for now. A number of research gaps have been identified. One of the gaps is while there is growing evidence of the benefits of human capital investment and mobility on development in African economies, most studies focus on how remittances affect poverty rates and development of African economies (Chami et al., 2005; Gupta, 2009\&Anyanwu, 2010). However little attention has been given to explore how remittancereceiving households utilise remittances and how remittance utilization could augment development at household level. Studies on determinants of remittance inflows have mainly focused on micro economic level using survey data (Shahbaz\&Aamir, 2009); (Karagoz, 2009) and (Buch, 2004). However, less has been done in sub - Saharan Africa and in East African region in particular. This paper contributes 
towards understanding Uganda at a household level scenario.A number of factors have been advanced to explain the pessimistic view on use of remittances. First, individual households make remittance use decisions, which make it difficult to establish how remittance monies are used. This has made much of literature in this area to be scarce and less empirical. Hence, there is a need to fully understand what determines household expenditure of remittances using nationally representative samples is clear in developing countries like Uganda. Hatton\&Williamson (1998) and Massey (1988) showed the effects of development on international migration, there is little or limited evidence to show how migration can potentially affect development of out-migrant sending communities. Literature shows that remittances have been urged to cause economic growth and consequently trigger development in the country, which deserves more attention specifically on the role of remittances in development. McKenzie \&Sasin (2007) argue that studies are needed on whether remittances are spent on consumption or investment and whether migrant families spend more on health and education, which are key investments that enhance development despite the increasing importance of remittances in total international capital flows to the country, the expenditure of remittances by households as it relates to development has not been adequately studied. The study therefore analyzes the effects of remittances on national development from a household perspective. Whereas remittances could be viewed as an engine for micro level development as it increases demand for consumer goods creating incentives for the establishment of new retail businesses and consequently may generate new local employment opportunities. Unfortunately this analysis is largely lacking in most African countries and Uganda inclusive.

\section{Data and methods}

Remittances survey for 2010 is used as source of data. Complementary log-log regression model was used because of the small numbers of households in the categories of interest (asymmetrically distributed). Survey weights were applied to data in order to account for the complex survey design including clustering and stratification. Remittance receipt status was determined by region of the household, number of rooms in the house, household main source of lighting fuel. Using remittances for development was determined by sex of the household head, household regional location, house ownership status sex, marital status and senders' residence. It is recommended that future - flow remittance receivables be used for collateral in securing loans.

The paper utilized data from the survey on personal transfers by Ugandans living abroad during the year 2010. This survey was the fourth in a series of annual surveys jointly conducted by Bank of Uganda and the Uganda Bureau of Statistics. The survey is designed to be nationally representative as well as representative to Uganda's rural and urban population. The regularity, frequency and consistency of this survey put it at an advantage over other surveys since this allows for improvement on methodology and data collection.

This, paper builds from the survey on personal transfers by Ugandans living abroad during the year 2010. The survey was designed to be nationally representative. From 4,410 households the survey methodology covered a total of 4,380 households selected randomly from 147 enumeration areas picked using the Probability Proportional to Size (PPS) approach. The sample data used for analysis consisted of 160 households that reported receiving worker's remittances in 2010.

Households with a recipient of worker's remittances were selected at the second stage from each of the selected enumeration areas. The dependent variables used had a value of I when a household spent part of its worker's remittances received on a household development enhancement and 0 otherwise. Spending on development enhancement in a household was defined for the purpose of the study as any spending on education, health, business and physical capital like land purchase. Household remittance recipient status was also measured by assigning a value of $\mathrm{I}$ when a household reported having received remittances and 0 for not reporting receiving remittances. In order to objectively state the determinants of migrant remittances use in Ugandan households, this paper focuses on the socio-economic status of remittance receiving households, as well as house hold head characteristics as a background for this study. The study analyzed two (2) dependent variables which include;

I. Household remittance receipt status (received transfers or not);

2. Use of remittances for development (Developmental use of remittances or non developmental use of remittances). Households that reported receiving worker's remittances in 2010 were 160 representing about $3 \%$ of the sample. The development aspect of remittances at household level is specifically assessed in this study depending on their use of the money transfers by the household and the key objective of this study is to examine whether households receiving money transfers are 
investing them in developmental (I) or nondevelopmental $(0)$ ventures. The complementary loglog regression is the preferred model for the study to estimate correlates of household international migrant presence, household remittance receipt status and use of remittances at the household in Uganda. Clog-log fits maximum likelihood models with dichotomous dependent variables coded as $0 / 1$ (or, more precisely, coded as 0 and not 0 ). The complementary log-log regression model is recommended for rare outcomes or in instances when data are asymmetrical and the outcome is binary. Survey weights were applied to data in order to account for the complex survey design including clustering and stratification. The logistic regression family that has generally been applied in the study model is one of the appropriate methods to deal with dependent variables of this nature. It studies the relationship between a categorical dependent variable (dichotomous) and one or more independent variables (quantitative or not). The dependent variable $(Y)$ indicates the possession or not of the characteristic in the population. Here this characteristic is "reception of transfer". The independent variables $\left(\mathrm{Xi}_{\mathrm{i}}\right)$ constitute the factor $(\mathrm{s})$ that lead to the variation of the explained variable. Independent variables represent the sociodemographic and migratory characteristics of households. If independent variable is qualitative, each k-I modality is transformed into a dummy variable and the remaining modality is considered as category of reference and will serve to compare with other modalities included in the model (Hosmer and Lemeshow, 1989). Given the nature of the data used in the study where only $3 \%$ reported receiving remittances, complementary log- log model is the preferred model in the multivariable analysis. Complementary log-log analysis is an alternative to logit and probit analysis, but it is unlike other estimators in that the transformation is not symmetric about 0 , i.e. it is skewed to the right. Typically this model is used when the positive (or negative) outcome is rare. As with other models in the logistic family, changes in the values of $X \beta$ produce nonlinear changes in the probability of success. The complementary log-log model is derived from the assumption that the error distribution (or distribution of the latent variable) follows a standard extreme value distribution (Powers and Xie, 2000). Additionally, aside from its use as an alternative probability model, this model has been used extensively to model grouped survival data. For individual level data, the parameters have a similar interpretation to those from the logistic regression model. The complementary log- log model is fitted as:

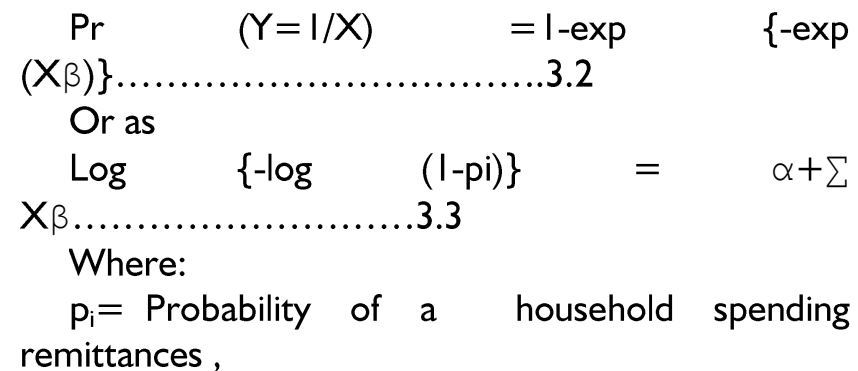

$\mathrm{I}-\mathrm{p}_{\mathrm{i}}=\quad$ Probability that a household does not receive remittances hence does not spend remittances

$\beta=$ Coefficients associated with explanatory variables,

$\mathrm{X}=\quad$ Explanatory variables which include, household head age, sex, education, literacy, employment status, number of people in dwelling unit, source of lighting fuel, source of cooking fuel, number of rooms in a house.

The estimation method employed reflects the dynamics (outcome variables) of remittances used by the recipient households that are reported as rare occurrences. For example, the recipient's households, which are influenced by individual as well as household characteristics, treat investing remittances in developmental or non-developmental ventures.

\section{Results}

Background characteristics of the respondents in various households are presented in Table I. Most of respondents (71.8\%) were males while a considerable proportion (28.2\%) were females. The reason for the big number of males is that most of them were household heads since Uganda is largely a patriarchal society. Majority of the respondents (28.8\%) were between 30 and 39 years while the least $(1.6 \%)$ were less than 20 years. Generally, most respondents were between ages 20-59.

Table I further shows that the largest proportion (69.2\%) of the respondents knew how to read and write (were literate) while $30.8 \%$ was illiterate. Majority of the respondents (30.9\%) reported that they had completed secondary level of education, and only $1.5 \%$ never had any education at all. Majority of respondents $(29.5 \%)$ were from the central part of the country, $25 \%$ were each from the eastern, $24.7 \%$ from western while the smallest proportion $(20 \%)$ was from the Northern part of Uganda.

Regarding employment and income earning status of household heads, almost all the respondents $(96.1 \%, 98.7 \%)$ were employed and were income earners respectively.Over a half $(57.5 \%)$ of the households had 5 or less usual members and 42.5 had 6 and more usual household members. More than three quarters of the respondents $(80.5 \%)$ had their 
own houses, $19.5 \%$ were renting. Over a half (56\%) of the respondents were living in houses which had I-2 rooms , $35.3 \%$ had $3-4$ rooms, while $8.7 \%$ had more than 5 rooms.

Regarding the main source of lighting fuel, majority of the respondent households $(78.1 \%)$ were using kerosene, oil, gas and lantern , $14.4 \%$ were using electricity, generator or solar , $6.2 \%$ were using firewood or candles and the least ( $1.6 \%)$ were using other means. As expected, for the main source of cooking fuel, majority of the respondent households (75.6\%) were using firewood , $22.6 \%$ were using charcoal, I.6\% were using gas, kerosene and other sources while the least $(0.2 \%)$ were using electricity for cooking.

A high proportion of respondents (89.8\%) reported that they did not have any member from their household living abroad while $10.2 \%$ reported that some of their household members lived abroad. Slightly over a half of the households with a member abroad (5I.5\%) had one member abroad and $48.5 \%$ had two or members abroad. Among the households that had members living abroad, a large majority $(96.3 \%)$ of respondents were not recipients of remittances while only $3.7 \%$ reported that they were recipients of remittances. Only $3.1 \%$ of the respondent households had senders while the rest $(96.9 \%)$ had no senders of remittances.

On use of international remittances by remittance- recipient households, most households (77.8\%) used remittances for non development ventures and only $22.2 \%$ used remittances for development ventures. $45.4 \%$ used remittances for non- consumption expenditure while $54.6 \%$ used remittances for consumption expenditure. The percentage of households that used remittances for education and health exclusively was $93.6 \%$ and $93 \%$ respectively.

Distribution of international Remittance Senders by Background characteristics is presented in Table 2 . Most of remittance senders (53.2\%) were between 30 and 39 years followed by $19.9 \%$ who were aged 40-49. The senders who were aged 29 and below and $50-59$ comprised of $18.4 \%$ and $7.4 \%$ respectively. The least $(2.2 \%)$ were 60 years and above. Most of the senders $(65.7 \%)$ were males while a considerable proportion (34.3\%) were females. As it would be expected the results show that majority of the senders were in their productive years of life. In addition the young are more likely to migrate in search for greener pastures of employment compared to those in older age groups. In turn the young workers are more likely to be target workers and they may be obliged to send money back home either to pay back for costs incurred by their families during the migration process or to care for their parents and siblings left behind.

Table 2 further shows that majority of the senders (35.3\%) had a degree, $30.9 \%$ had completed secondary level of education, and $19.1 \%$ had completed post secondary level of education, 13.2\% had completed primary and only $1.5 \%$ never had any education at all. The results could be explained that more educated senders earn more income compared to those who are less educated. In addition, this is a reflection of skilled migrants who are likely to attract better paying jobs compared to less skilled and with a higher income, the senders are likely to send a higher amount of money back home.

The largest proportion (65.0\%) of the remittance senders were married while $28.5 \%$ were not married and only $6.6 \%$ of the senders were either widowed, divorced or separated. Most senders (64.2\%) had lived abroad for 5 years or less, while $35.8 \%$ had lived abroad for 6 years or more. Marriage is understood to come with responsibilities for the family left behind and may be a reflection of the non- written contractual agreement between a household member and household members left behind. The agreement may be to improve the household conditions of the households after sending the migrant abroad through remittances. Married migrants who left their families in the country of origin could be obliged to keep their responsibilities of paying school fees for children and taking care of the daily basic needs for the households hence a higher likelihood of sending remittances.

The senders who had no dependent child were $46.9 \%, 32 \%$ had I-2 children dependents while $21.1 \%$ had 3 or more dependent children. This result is different from what would be expected. It would be expected that senders with no biological dependent children would be more compared to those with dependent children. However the results show a different scenario. This can be explained by the results in age groups of the senders. It was found that most senders were young and may be more likely not to be having any dependent child. Having no dependent child in Uganda's case and probably elsewhere in Africa does not mean that one has no dependants. In Africa where society looks at children as insurance for old age it is likely that most of the senders with no dependent children were sending money to either, parents, siblings and other family members or relatives. It can also be explained that most of the senders send money for purely altruism reasons while others may send money because they have family property inheritance interests.

Over half of the remittance senders $(56.9 \%)$ lived outside the African continent and $43.1 \%$ lived in Africa. This could be explained by the better http://aps.journals.ac.za 
employment opportunities that the continents outside Africa offer as well as better working conditions that other continents offer which may include better payment, respect for human rights and dignity among others.

As expected, most of the remittance senders $(95.6 \%)$ were working. Sending remittances is directly associated with ability to send remittances though this may not be automatic. Besides the study focused on Ugandan population that was living and working abroad.

According to the table, few households (3.1\%) reported having senders. Majority of senders (39.4\%) were reported to be sending money to their siblings, $23.4 \%$ sent remittances to other relatives and friends, $21.9 \%$ sent remittances to their children while $10.2 \%$ and $5.1 \%$ sent remittances to their spouses and parents respectively.

Factors that determine household receiving international remittances from a migrant are examined in Table 3. Results of adjusted odds ratios from multivariable complementary log regression of household international remittances receipt status in Uganda are presented.

Model results in Table 3 shows that household international remittance receipt status was significantly determined by region of the household, number of rooms in the house, household main source of lighting fuel, a household having a member abroad and a household having at least one remittance sender abroad and they were significant.

Highest education level completed by the household head, literacy status of a household head, and owning a house or renting it, household main source of cooking fuel were significantly associated with a household receiving remittances at bi-variate level but they were not significant in the model and therefore were not determinants of household remittances receipt status. Fleur and Edwards, (2007) further argue that migrant households have more adults with primary education than non migrant households, and households with continental migrants have the most adult members with secondary schooling. From the findings the authors made in a migration and income diversification survey within Burkina Faso, it was also discovered that households with migrants of either type are larger and have an older household head than non-migrant households.

Receiving remittances by households was found to be significantly determined by a household having a 5 or more rooms $(O R=5.0, p=0.00 I)$. There were increased odds of receiving international remittances for households that had 5 or more bed- roomed houses compared to households that had I-2 bedroomed houses. Results show that households with 5 or more bed-roomed houses were about 5 times more likely to receive remittances as opposed to households with fewer rooms (I-2 rooms). In Burkinafaso, households with inter-continental migrants also have more dependents (members who were economically inactive). Household size is related to labor availability and thus, in a context of imperfect hired labor markets, may explain activity choices and incomes (Fleur and Edwards, 2007).

Table 2: Distribution of remittance senders by background characteristics

\begin{tabular}{|l|l|l|}
\hline Household Senders status & Frequency & Percent \\
\hline Households with no senders & 4,243 & 96.9 \\
\hline Households with senders & 137 & 3.1 \\
\hline Total & 4,380 & 100.0 \\
\hline Household head's relationship to sender & 14 & 10.2 \\
\hline Spouse & 7 & 5.1 \\
\hline Parent & 30 & 21.9 \\
\hline Children & 54 & 39.4 \\
\hline Siblings & 32 & 23.4 \\
\hline Others & 137 & 100.0 \\
\hline Total & \multicolumn{2}{|l|}{} \\
\hline Age of the sender & 25 & 18.4 \\
\hline$<=29$ years & 71 & 52.2 \\
\hline $30-39$ years & 27 & 19.9 \\
\hline $40-49$ years & 10 & 7.4 \\
\hline $50-59$ years & 3 & 2.2 \\
\hline $60+$ years & 136 & 100.0 \\
\hline Total & \multicolumn{2}{|l|}{} \\
\hline Sex of the sender & 90 & 65.7 \\
\hline Male & 47 & 34.3 \\
\hline Female & 137 & 100.0 \\
\hline Total &
\end{tabular}




\begin{tabular}{|l|l|l|}
\hline Highest level of education of sender & 2 & 1.5 \\
\hline None & 18 & 13.2 \\
\hline Primary & 42 & 30.9 \\
\hline Secondary & 26 & 19.1 \\
\hline Post secondary & 48 & 35.3 \\
\hline Degree & 136 & 100.0 \\
\hline Total & \multicolumn{3}{|l|}{} \\
\hline Marital status of sender & 39 & 28.5 \\
\hline Never Married & 89 & 65.0 \\
\hline Married & 9 & 6.6 \\
\hline Widowed, Divorced/ Separated & 137 & 100.0 \\
\hline Total & \multicolumn{2}{|l|}{} \\
\hline Years lived abroad by Sender & 88 & 64.2 \\
\hline$<=5$ years & 49 & 35.8 \\
\hline $6+$ years & 137 & 100.0 \\
\hline Total & \multicolumn{2}{|l|}{} \\
\hline No of Senders' Dependent children & 60 & 46.9 \\
\hline No Child & 41 & 32.0 \\
\hline I-2 Children & 27 & 21.1 \\
\hline 3+ Children & 128 & 100.0 \\
\hline Total & \multicolumn{2}{|l|}{} \\
\hline Senders' residence & 59 & 43.1 \\
\hline Africa & 78 & 56.9 \\
\hline Others & 137 & 100.0 \\
\hline Total & 131 & 95.6 \\
\hline Work status of the senders & 6 & 4.4 \\
\hline Working & 137 & 100.0 \\
\hline not working & \multicolumn{2}{|l|}{} \\
\hline Total & \multicolumn{2}{|l|}{} \\
\hline
\end{tabular}

Table 3: $\quad$ Results of adjusted odds ratios from multivariable complementary log regression of household remittances receipt status in Uganda.

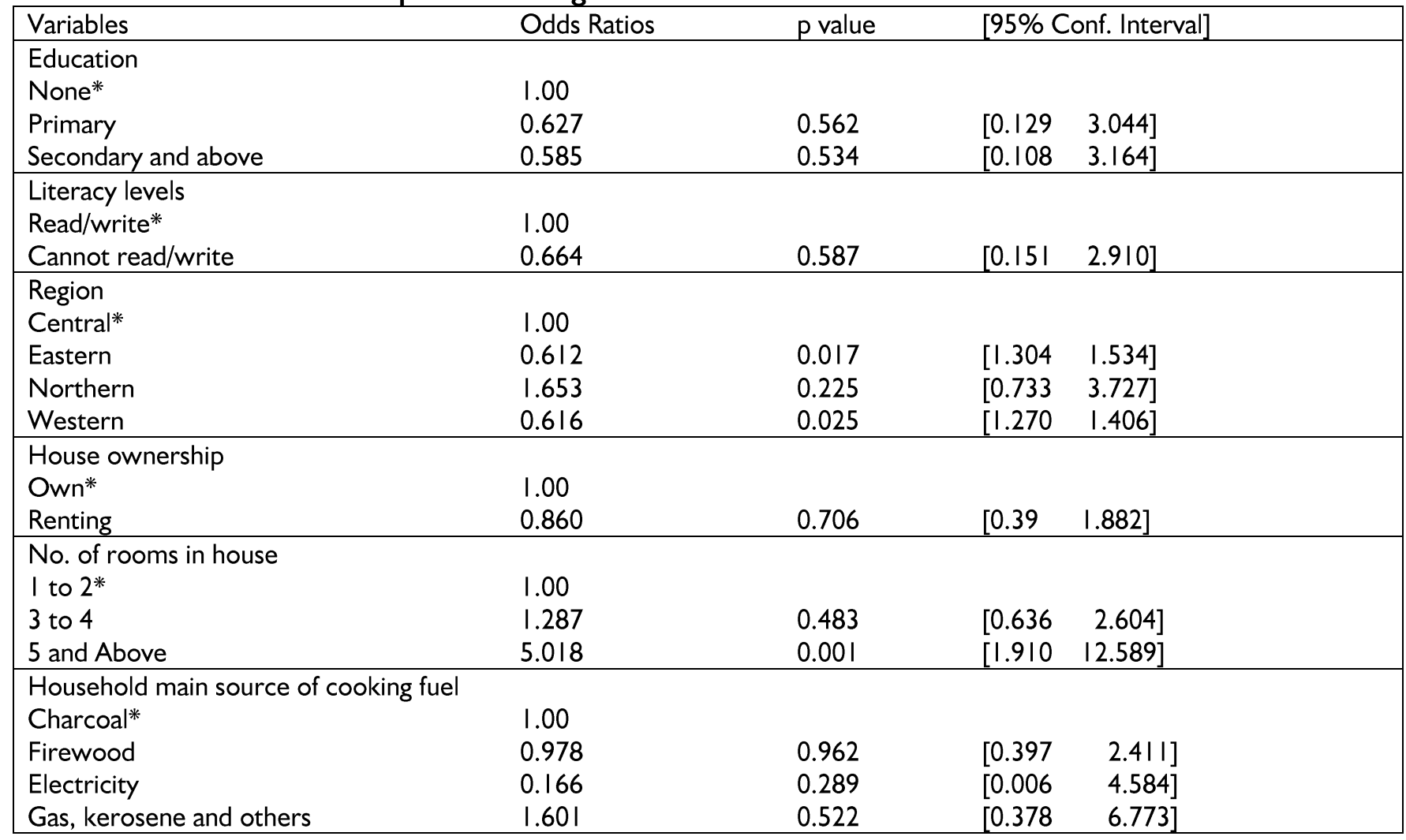




\begin{tabular}{|c|c|c|c|c|}
\hline $\begin{array}{l}\text { Household main source of li } \\
\text { Kerosene oil gas, lantern* }\end{array}$ & 100 & & & \\
\hline Electricity, generators & 1.463 & 0.039 & {$[1.614$} & $3.486]$ \\
\hline Firewood, candles & 0.861 & 0.828 & {$[0.224$} & 3.309] \\
\hline Household member abroad & & & & \\
\hline Yes* & 1.00 & & & \\
\hline No & 0.034 & 0.000 & {$[0.014$} & $0.083]$ \\
\hline
\end{tabular}

*Reference category

Number of rooms is a wealth index composite factor and therefore shows just like in the household migration model, households three or more rooms in the house were financially capable to send a migrant abroad, and the same households in turn study by Karagoz (2009). He found that at household level remittances receipts improve incomes of recipients and reduces inequalities as well as promoting entrepreneurial activities thus meeting health costs of the household. However, according to Alejandro, (20I0), remittances tend to go to smaller households with fewer children and more elders and to families with few working adult members but more permanent migrants.

The odds of receiving international remittances by a household increased with a household that reported using electricity or generators for lighting fuel compared to households that reported using kerosene, oil, gas or lantern $(O R=1.5, p=0.039)$. Again as wealth index indicator, electricity is usually used by households in urban areas or in households that are wealthier. This means that households that used electricity and gas had a higher living standard and therefore likely to send members abroad and households with members abroad were more likely to receive remittances. Therefore results show that use of electricity was a positive indicator and a determinant for a household to receive remittances. In addition to the findings from remittance surveys that have consistently showed remittances as an issue of urban households are hereby confirmed by this result. were more likely to receive international remittances compared to the households that had fewer rooms ( $\mathrm{I}-2$ bedrooms). Therefore remittance receipt for a household can transform a household from a lower to a higher wealth quintile as found in Turkey in a

The region where the household was located and a household having a member abroad showed a negatively associated of household receiving remittances. Results in table 4 showed that the odds of receiving international remittances by households in the eastern region of Uganda $(O R=0.6, p=0.017)$ and western Uganda $(O R=0.6, p=0.025)$ were reduced compared to households that were in central region.

The result is expected as the central region is where most urbanized households are located including Uganda's primate city- Kampala and the neighbouring sub-urban areas that have developed as a result of Kampala city. Urban areas are more likely to have migrants abroad compared to rural areas. While rural residents are likely to migrate to the city and the surrounding urban areas, urban residents are in turn likely to migrate abroad owing to the cyclical migration. This in turn is expected to result into migrants abroad sending remittances to the households that they left behind for various reasons including altruism.

Table 4 presents results of the application of multivariable complimentary log regression of household use of remittances for development.

Table 4: Results of adjusted odds ratios from multivariable complementary log regression of household remittances use for development in Uganda.

\begin{tabular}{|c|c|c|c|c|}
\hline Variables & Odds Ratios & $p$ value & {$[95 \% \mathrm{C}$} & onf. Interval] \\
\hline $\begin{array}{l}\text { Female* } \\
\text { Male }\end{array}$ & $\begin{array}{l}1.00 \\
0.145\end{array}$ & 0.000 & {$[0.101$} & $0.425]$ \\
\hline $\begin{array}{l}\text { Education } \\
\text { None* } \\
\text { Primary } \\
\text { Secondary and above }\end{array}$ & $\begin{array}{l}1.00 \\
4.282 \\
5.032 \\
\end{array}$ & $\begin{array}{l}0.267 \\
0.222 \\
\end{array}$ & $\begin{array}{l}{[0.328} \\
{[0.377}\end{array}$ & $\begin{array}{l}55.837] \\
67.158]\end{array}$ \\
\hline $\begin{array}{l}\text { Literacy levels } \\
\text { Read/write* } \\
\text { Cannot read/write }\end{array}$ & $\begin{array}{l}1.00 \\
2.796\end{array}$ & 0.306 & {$[0.390$} & $20.060]$ \\
\hline $\begin{array}{l}\text { Region } \\
\text { Central* } \\
\text { Eastern }\end{array}$ & $\begin{array}{l}1.00 \\
2.103\end{array}$ & 0.174 & {$[0.720$} & $6.141]$ \\
\hline
\end{tabular}




\begin{tabular}{|c|c|c|c|c|}
\hline Northern & 0.486 & 0.036 & {$[0.122$} & $0.193]$ \\
\hline Western & 2.889 & 0.015 & {$[0.772$} & $0.910]$ \\
\hline $\begin{array}{l}\text { House ownership } \\
\text { Own* } \\
\text { Renting }\end{array}$ & $\begin{array}{l}1.00 \\
2.390\end{array}$ & 0.012 & {$[1.797$} & $7.172]$ \\
\hline $\begin{array}{l}\text { No. of rooms in house } \\
1 \text { to } 2^{*} \\
3 \text { to } 4 \\
5 \text { and Above }\end{array}$ & $\begin{array}{l}1.00 \\
1.818 \\
0.780\end{array}$ & $\begin{array}{l}0.289 \\
0.044\end{array}$ & $\begin{array}{l}{[0.602} \\
{[1.179}\end{array}$ & $\begin{array}{c}5.492] \\
3.386]\end{array}$ \\
\hline
\end{tabular}

*Reference category

Using remittances by households for development purposes was significantly determined by a household being located in the western region of Uganda $(O R=2.9, p=0.015)$. Results showed that households located in the western region of Uganda had increased odds of using remittances for development purposes compared to households from the central region of Uganda. As indicated before the central region is largely urban and therefore with more migrants. As migrants are positively selected in terms of wealth, the migrants whose households are in central region are likely to spend money on other uses such as leisure, household consumption that do not directly augment household development. On the other hand remittances senders from households in the western region are more likely to send money to their households to be used for development ventures since their households may be poorer and also largely located in rural Uganda compared to households in the central region. Remittances in western Ugandan households are likely to be invested in house construction, land purchase compared to households in central Uganda who may be well off enough to carry out development without remittances.

Earlier studies posited that migration was likely to increase rural inequality, because only relatively better-off households were able to finance a member's search for better employment in urban areas, or abroad (Lipton, 1980; Stahl, 1982). More recently, it has been found that migration patterns in East European and former Soviet Union countries are such that richer households receive greater remittances than do poorer households (World Bank, 2007).

Results showed that the odds of households using international remittances for development purposes reduced for households that were located in the northern region of Uganda $(O R=0.5, p=0.036)$. Households located in the northern region had less odds of using remittances for development purposes compared to households in the central region. Using remittances for development may be related to behavioural aspects of expenditure but in this case, it is noted that the northern region was still affected by the war in the region. It is therefore understandable that in situations of war, money that is received by households is likely to be used for immediate needs of the household like food and clothing compared to relatively stable regions. Therefore households in northern region in 2010 during the survey were likely to have been unstable compared to central region and use of remittances for non- developmental ventures as indicated in the explanation may be a plausible explanation as the future of such households may not be certain.

This result is a confirmation that migration may contribute positively to social and economic development in migrant-sending areas. The context of remittances use for development was stressed by Hein De Hass (2006) that it cannot be fundamentally altered by individual migrants. He postulated that migration is a household strategy to overcome local constraints on economic production and development. He pointed out that migration impacts are therefore highly context-sensitive. Depending on the specific development context, migration and remittances may enable people to retreat from, just as much as to invest in, local economic activities. He further observed that remittances, like any other source of external income, give households greater freedom to concentrate their activities and allocate investment to those economic sectors they perceive as most stable and profitable. It is this very capabilityenhancing potential of migration that also increases the freedom of households to settle elsewhere, depending on the general development context.

Household renting house significantly determined use of remittances for development purposes $(O R=2.4, p=0.012)$. Use of international remittances for development was found to be positively determined by renting a house compared to owning a house. Households that were renting a house had increased odds of using remittances for development purposes. It could be argued that one of the goals for a household member migrating is that they have entered a contractual agreement with their household members to improve the standards of living by a member migrating. Remittances in this case are easily seen as a remedial from poverty and 
to improve standards of living of households. As such remittances sent for such households were more likely to be used for developmental purposes such as building their own housing unit or land purchase or investment into business which are all ventures that augment development at household level. Therefore, the increased odds of investing remittances in developmental ventures for households that were renting the house were not a surprise.

The sex of a household head was a predictor for use of remittances for development by household. Male headed remittance-receiving households had reduced odds of using remittances for development related activities compared to female-headed remittance receiving households $(O R=0.145, p=0.000)$. This finding relates to the opportunities that a migrant household may have to forego in order to send a family member abroad especially if the migrant is a household head. Male household heads were found to be less likely to use remittances for developmental purposes as opposed to their female counterparts.

A household having a 5 or more roomed-house also determined household use of remittances for development $(O R=0.8, p=0.044)$. Table 4 showed a negative association of household use of remittances for development ventures. Results show that households with 5 or more bed-roomed houses were less likely to use remittances for development purposes as opposed to households with fewer rooms ( $1-2$ rooms).

While the number of rooms is arguably a wealth index composite factor, the expenditure pattern of wealthy households differs from the expenditure patterns of the poor household. The number of rooms and use of remittances is one of the indicators to confirm the difference in expenditure. It has been argued that migration is an expensive venture and therefore benefits households that are already rich, educated and located in urban areas as already found out before. Money received from household members may easily be spent on leisure and daily household consumption and in ventures that do not directly augment development at household level since it may not be a priority for such households.

Although consumption may be predominant, results from surveys of returned migrants found that a non-negligible share of remittances is invested in capital formation. The World Bank (2006) claimed that the majority of remittances are utilized for funding consumption of food and clothing; large quantities are also used for education and savings (over 10\%); smaller amounts are spent on direct investment in business (less than $5 \%$ ).

\section{Discussion}

Remittances are part of a private welfare system that transfers purchasing power from relatively richer to relatively poorer members of a family, or a community. They reduce poverty, smooth consumption, affect labor supply, provide working capital, and have multiplier effects through increased household spending. These transfers have typically been targeted to female-headed households (Sanjeez Gupta, et al, 2009).

Following the massive out migration of the 1970s and 1980s, remittances from abroad have become a significant source of household income throughout the 1990s. In 1997, 14\% of rural and 15\% of urban households received remittances from relatives or friends living abroad (Edwards \&Ureta, 2003). Income from remittances expands the household budget constraint allowing some families to find it optimal that their children acquire more schooling than they would acquire otherwise (Alejandra \&Manuelita, 2003).

Therefore in Uganda it is expected that households from the central region would be the highest receivers of remittances since they are the highest senders of migrants( Bank of Uganda, 2010). In this analysis the argument in the migration model where it was found that households from northern Uganda are more likely to have migrants compared to households from central Uganda does not hold as the model did not control for reasons for migration.

A study from Mexico by Zarate-Hoyos (2004) also found that urban households receiving remittances from family members abroad had increased by $100 \%$ while households in rural areas had increased by $75 \%$. This indicated that urban households in Mexico were more likely to have members abroad compared to areas that are rural.

Apart from persons sent abroad on sponsorship by government and other agencies, sending a migrant abroad is further considered an aspect related to wealth situation of a household as well as the household's strategic location to migration opportunities. Evidence from Bangladesh showed that a household's wealth-related capital (mainly in the form of land) is crucial in shaping heterogeneous migration behaviour towards different typologies of migration. Asset-poor farm households were found more likely to enter into domestic migration, which has lower entry costs, and lower absolute returns. Entry into high-return migration (i.e. international migration), in which most households would engage within a 'first-best' perspective, was found to be restricted to richer and large-holder households which were more likely to be in urban areas (Mendola, M.2008). 
Receiving remittances by households was found to be positively determined by a household having a member living abroad. Households that had no member living abroad had reduced odds $(O R=$ 0.034, $p=0.00$ ) of receiving international remittances. Although it may appear obvious that households that have a member living abroad receive remittances it depends on several factors which include, number of years lived abroad, the country where the migrant is, relationship of the migrant with the household. It should also be noted that not all remittances receiving households in the survey received remittances from household members. Some households reported receiving remittances from friends, relatives and well-wishers. However as expected, households that had a member living abroad had more odds of receiving remittances from abroad.

The most preferred way parents would love their children go through in their life path was that they desired that a child finishes University in Uganda, goes for further studies abroad, works for some time as they support others back home, come back to have a successful career, get married, have children and support the wider family and relatives. But migrations may also affect educational attainments of those who do not choose to move, both in the destination and the origin countries. Migrations may lead to a change in the skill base of both sets of countries, affecting average levels of education and possibly generating educational externalities and new incentives for human capital investments (Dustman, 2005).

People with skills are portrayed as relocating from South to North due to a variety of push and pull factors. These are almost always seen as a logical response to differentials in wages and income, lifestyles, personal security, political participation, prospects for career and professional advancement, children's futures, and so on. In the developed world, grayingpopulations and consequent skills shortages are seen as major factors precipitating a new global hunt for skills from the developing world (Crush and Hughes, 2009).

Indeed, recent literature sees emigration as potentially beneficial to households in the home countries. Specifically, authors such as Mount Ford (1997) and Beine, Docquier, and Rapport (2003), argue that the possibility of emigration raises the expected return on education at home, and thus is likely to increase investment in education, which has positive effects on productivity and growth. Beine, Docquier, and Rapport (2003) found a positive and highly significant effect of migration prospects on gross human capital formation. The increased stock of human capital in the home country may on average have a positive effect on institutions. This argument is in line with the works of Waddington (2003) who posits that absence of a fully developed cash economy with inadequate social protection people send remittances as a contribution to family risk reduction to ensure the well-being of their households in the present and future.

To support the findings on use of remittances for development, findings by Adams (2006) from household-level research found a relationship between remittances and poverty. His results showed that for those countries which are fortunate enough to receive international remittances, they tend to reduce the level and depth of poverty. Also in Guatemala, the receipt of international remittances reduces the level of poverty (measured by the poverty headcount index) by $1.6 \%$ and the depth of poverty (measured by the poverty gap index) by $12.6 \%$. In rural Mexico, simulation experiments suggest that a $10 \%$ increase in international remittances will reduce the level of poverty by $0.77 \%$ and the depth of poverty by $0.53 \%$. In both countries, international remittances tend to reduce poverty because households in the lower end of the income distribution are able to produce international migrants and to receive international remittances. Although previous work has suggested that international remittances tend to be consumed, rather than invested, results show that households receiving remittances actually spend less on consumption, food, and more on investment, education and housing, than other types of households.

These results offer indirect evidence that use of international remittances for activities that augment development capabilities at a household level that is posited in the argument is at work. Altogether, the theoretical reasoning and empirical findings suggest that international remittances can be invested in activities that are associated with development enhancement especially in human capital development and investment. More specifically, expenditure of remittances is largely on health expenditure, education expenditure, general household expenditure and business investment but the determinant for expenditure of remittances on each activity varies. Factors that are associated with the likelihood that remittances are used for identified activities that enhance development at the household level theoretically and empirically have been explored in this study.

\section{Conclusion}

This paper was an investigation of the international migrant's remittances behaviour in Uganda. Results show that a household that had a member abroad 
also had higher chances of receiving remittances compared to the household with no member abroad. Results on the contrary found household and household head characteristics significantly associated with remittance receipt status of a household. Use of international remittances for development of households was significantly determined by sex of the household head, regional location of the household, house ownership status and number of rooms in the house. It is therefore recommended that government should leverage migration opportunities for women and also expand migration opportunities across all regions of the country since it augments development for households with migrants.

\section{References}

Acosta, P. 2007. "Entrepreneurship, Labor Markets, and International Remittances: Evidence from El Salvador." In International Migration, Economic Development and Policy, edited by C. Ozden and M. Schiff. New York: World Bank and Palgrave Macmillan.

Adams, R. H., \&Cuecuecha, A. (20I0).Remittances, household expenditure and investment in Guatemala. World Development, 38(II), 16261641.

Adams Richard H and John Page. (2005). Do international migration and remittances reduce poverty in developing countries? World Development, 33(10), 1645-1669.

Adams, R. H., \& Page, J. (2005). Do international migration and remittances reduce poverty in developing development, 33(10), 1645-1669.

Adams, Richard H. 2006. "Remittances, Poverty, and Investment in Guatemala." In ÇaglarÖzden and Maurice Schiff (eds.) International Migration, Remittances, and the Brain Drain. World Bank, Washington D.C.

Adepoju, A. (1995). Emigration dynamics in Subsaharan Africa.International Migration (Special issue on emigration dynamics in developing countries), 33(3-4).

Agarwal, R., \& Horowitz, A. W. (2002). Are international remittances altruism or insurance? Evidence from Guyana using multiple-migrant households. World Development, 30(II), 20332044

Airola, J. (2007). The use of remittance income in Mexico.Internatonal Migration review, 4I(4), 850850.

Albert B. David McKenzie Melanie Morten and Hillel Rapoport. (20II). Remittances and the Brain Drain Revisited: The Microdata Show That More Educated Migrants Remit More. Mig World Bank
Economic Review, World Bank Group, 25(I), I32-156.

Ammassari, S. (2003). From nation-building to entreneurship: the impact of elite return migrants in Cote d'ivoire and Ghana. International Workshop on migration and poverty in West Africa, 13-14 March 2003.University of Sussex.

Amuedo-Dorantes C. S. Pozo and C. VargasSilva.(20I0). remittances in small island developing states.Journal of development studies, 46(5), 94I960.

Asfar, R. (2000). Rural Urban migration in Bangladesh: Causes Consequences and Challenges. Dhaka: University Press limited.

Athukorala, P. (1993). Manufactured Exports from Developing Countries and their terms of trade: $A$ re-examination of the Sarkar-Singer Results.2I(10), I607-1613.

Athukorala, P. (1993). Manufactured Exports from Developing Countries and their terms of trade: $A$ re-examination of the Sarkar-Singer Results.Athukorala, $P$ (1993) Manufactured Exports from Developing Countries and their terms of trad2I(10), 1607-1613.

Atman, C. J., Sheppard, S. D., Turns, J., Adams, R. S., Fleming, L. N., Stevens, R., ... \&Yasuhara, K. (20I0). Enabling Engineering Student Success. Center for Advancement of Engineering Education.

Aydas, O. T., Metin-Ozcan, K., \&Neyapti, B. (2005). Determinants of workers' remittances: the case of Turkey. Emerging Markets Finance and Trade, 4I(3), 53-69.

Azam Jean-Paul and Gubert Flore. (2005). Migrant Remittances and Economic development in Africa: A Review of Evidence. IDEI Working Paper 354.

Bagasao Ildefonso Jr. (2003). Overseas Filipino workers in the national development agenda: Perspective from a migrant advocate. Quezon cityphilips: Ateneo de manila university.

Ballard, R. (2003). A Case of Capital-Rich UnderDevelopment: The Paradoxical Consequences of Successful Transnational Entrepreneurship from Mirpur. Contributions to Indian Sociology, 37(I\&2), 25-58.

Beine, M. A., Docquier, F., \&Rapoport, H. (2003). Brain drain and LDCs' growth: winners and losers.

Beine, M., Docquier, F., \&Rapoport, H. (2008). Brain drain and human capital formation in developing countries: Winners and losers. The Economic Journal, II8(528), 63I-652.

Boucher Bradford and Barham Stephen. (1998). Migration, remittances and inequality: Estimating the net effects of migration on income distribution. Journal of Development economics, 55, 307-33I. 
Boucher, D. (1998). Political theories of international relations (Vol. 383). Oxford: Oxford University Press.

Briere B. d. I. Janvry A. d. Lambert S. and Sadoulet E. (1997). Why do migrants remit? An analysis for the Dominican Sierra.FCND Discussion Paper, 37.

Brière D. B. Sadoulet E. De Janvry A. and Lambert S. (2002).Treating Adult survivors of severe childhood abuse and neglect: Further development of an integrative model.journal of Development Economics, 68, 309.

Brink, J. (199I). The effect of emigration of husbands on the status $f$ their wives: an Egyptian case. International journal of Middle East Studies no 23, 20I-2II.

Brockerhoff $M$ and Biddlecom Ann E. (1999).Mlgration, Sexual behaviour, and the risk of HIV in Kenya.International Migration REview, 33(4), 833-856.

BrockerhoffM.andBiddlecom A.E. (2002). 'Migration, Sexual Behaviour and the Risk of HIV in Kenya' in International Migration Review.A Comparative Study of Land Tenure in Four Countries: Uganda, Tanzania, Malawi and Kenya, 33(4)(31), 833-856.

Buch, C. M., \&Kuckulenz, A. (2004). Worker remittances and capital flows to developing countries. ZEW-Centre for European Economic Research Discussion paper, (04-03I).

Byerlee, D. (1972). Research on migration in Africa: past present and future.

Byerlee, D., Eicher, C., Liedholm, C., \& Spencer, D. (1977).Rural Employment in Tropical Africa. East Lansing: Michigan State University, Dept. of Agricultural Economics.

Caldwell, J. (1969). African rural-migration: the movement to Ghana's towns. New York: Columbia University press.

Carling Jørgen. (2008). The determinants of migrant remittances. Oxford Review of Economic Policy, 24(3)., 582-599.

Carling, J. (2005).Migrant Remittances and Development cooperation.PRIO report I/2005, International peace research institute, PRIO.

Chami R. Barajas A. Cosimano T. Fullenkamp C. Gapen M. and Monielp.(2008). Macroeconomic Consequences of Remittances.IMF Occasional Paper.

Chami R. Fullenkamp C. and Jahjah S. (2005). Are Immigrant Remittance Flows a Source of Capital for Development? IMF Staff Papers, 52, 55-8I.

Chami R. Fullenkamp C. and Jajjah S. (2003). Are Immigrant Remittances Flows a Source ofcapital for Development.IMF Working Paper, 189.

Chami Ralph ConnelFullenkamp and Samir Jahjah. (2005). Are Immigrant Remittance Flows a Source of Capital for Development? International Monetary Fund Working Paper, 3, 189.

Chimhowu A J Piesse and C. Pinder. (2005). The socioeconomic impact of remittances on poverty reduction, In S.M. Maimbo and D. Ratha (Eds), REmittances: Development Impact and Future prospects. Washington, DC: The World Bank.

Clare W. (2003).Livelihood outcomes of migration for poor people.

Collier P.and Lal D. (1984). Why Poor People Get Rich: Kenya 1960-79. World Development, 12 (10), 1007-18.

Connell J. and Conwey D. (2000). Migration and Remittances in Island Microstates: a Comparative Perspective on the South Pacific and the Caribbean. Journal of Urban and Regional Research, 24, 52-78.

Daianu, D. (200I). Balance of payementsfianancing in Romania - The role of Remittances. Romanian Center for Economic policies.

Daniel Daianu and ThanosVeremēs.(200I). Balkan Reconstruction.Psychology Press.

De la Briere, B., Sadoulet, E., De Janvry, A., \& Lambert, S. (2002). The roles of destination, gender, and household composition in explaining remittances: an analysis for the Dominican Sierra. Journal of Development Economics, 68(2), 309-328.

De Haan A. Brock K.andCoulibaly N. (2002). Livelihoods and Institutions: Contrasting Patterns of Migration in Mali. Journal of Development Studies, 38(5).

De Haan, A. (2000). Migration and Livelihoods: Case Studies in Bangladesh, Ethiopia and Mali. Institute of Development Studies Research Report, 46.

De Haan, A. (2000). Migrants, livelihoods and rights: the relevance of migration in development policies.

De Haas, R., \&Naaborg, I. (2005). Does foreign bank entry reduce small firms' access to credit? Evidence from European transition economies.

De Haas H and Plug R. (2006). Cherishing the goose with the golden eggs: Trends in migrant remittances from Europe to Morocco 19702004.International Migration Review, 40(603634).

De Haas, H. G. (2003). Migration and development in Southern Morocco.The disparate socioeconomic impacts of out-migration on the Todgha Oasis Valley. [SI: sn].

Deb S. Thomas M. and Bright C. (200I). Mental disorder in adults with intellectual disability 2: The rate of behaviour disorders among a communitybased population aged between 16 and 64 years. Journal of Intellectual Disability Research, 45(6), 506-5।4.

http://aps.journals.ac.za 
Deshingkar P Start D. (2003). Seasonal Migration for Livelihoods in India: Coping, Accumulation and Exclusion. ODI Working Paper(220).

Edwards Alejandra and ManuelitaUreta. (2003). International Migration, Remittances and Schooling: Evidence from El Salvador. Journal of Development Economics, 72, 429-46I.

Egesa, K. (20|4). Worker's Remittances and Household Capital Accumulation Boon in Uganda. Working Paper No. 03/20 I4, Bank of Uganda

Eicher, C. K. Et DC Baker,(1984).". Étude Critique De La Recherche Sur Le DéveloppementAgricoleEnAfrique SubSaharienne". Michigan, IRDC, 425p.

Fayissa, B., \&Nsiah, C. (2008). The impact of remittances on economic growth and development of Africa. Department of Economics and Finance Working Paper Series, February 2008.

Gamlen, A. (20|4). The new migration-anddevelopment pessimism. Progress in Human Geography, 38(4), 58I-597.

Hosmer D. W. Jr. S. A. Lemeshow R. X. Sturdivant. (20I3). Applied Regression (3rd ed.). Hoboken, NJ Wiley.

Konseiga, A. (2005). Household Migration Decisiona as a Survival Strategy: The case of Burkina Faso.ZEF discussion papers on development policy.Discussion Paper 1819.

Lewis, W. (1954).Economic Development with Unlimited Supplies of Labour.

Lillard, L. A., \& Willis, R. J. (1997). Motives for intergenerational transfers: Evidence from Malaysia. Demography, 34(I), I I 5-I34.

Lipton, M. (1980). Migration from the rural areas of poor countries: The impact on rural productivity and income distribution. World Development, 8, I-24.

Lowell, B. L., \& Findlay, A. (200I). Migration of highly skilled persons from developing countries: impact and policy responses. International migration papers, 44, 25.

Lucas, R. E., \& Stark, O. (1985). Motivations to remit: Evidence from Botswana. The Journal of Political Economy, 901-918.

Lucas, R. (2004). Motivations to Remit: Evidence from Botswana. Journal of Political Economy, 93(5), 90I-9I8.

Macharia, K. (2003.). Migration in Kenya and Its Impact on the Labor Market.Conference on African Migration in Comparative Perspective. Johannesburg, South Africa.

Martin P. S. Martin and P. Weil. (2002). Best practice options: Mali. International Migration, 40(3), 8799.
Masse, L. C., \& Tremblay, R. E. (1997).Behavior of boys in kindergarten and the onset of substance use during adolescence. Archives of general psychiatry, 54(I), 62-68.

Masse, L. N., \& Barnett, W. S. (2002).A benefit-cost analysis of the Abecedarian early childhood intervention. Cost-Effectiveness and Educational Policy, Larchmont, NY: Eye on Education, Inc, I57-I73.

Massey Douglas S. Joaquin Arango Graeme Hugo Ali Kouaouci Adela Pellegrino and J. Edward Taylor. (2005). Worlds in Motion: Understanding International Migration at the End of the Millennium.Oxford University Press.

Massey DS Arango J Hugo G Kouaouci A Pellegrino A Taylor JE. (1998). Massey DS, Arango J, Hugo G, Kouaouci A, PeWorlds in motion: Understanding international migration at the end of the millennium. Oxford: Clarendon Press.

Massey DS Arango J Hugo G Kouaouci A Pellegrino A Taylor JE. (1998). Worlds in motion: Understanding international migration at the end of the millennium. Oxford: Clarendon Press.

Massey DS Arango J Hugo G Kouaouci A Pellegrino A TaylorjE. (1993). Theories of international migration: A review and appraisal. Population and Development Review, 19, 431-66.

Massey, D. (1988). Economic development and International Migration in comparative perspective.Population and Development review, 14(3), 383-413.

Massey, D. (1989). International Migration in Comparative Perspective.

Massey, D. (1990). Social Structure, Household Strategies, and the Cumulative Causation of Migration.Population Index, 56, 3-26.

Massey, D. (|99|). Economic Development and International Migration in Comparative Perspective.In Determinants of Migration from Mexico, Central America, and the Carribean. (S. W. Díaz-Briquets, Ed.) Boulder, Colorado: Westview Press.

Massey, D., R. Alarcon, J. Durand, and H. Gonzalez. 1987. Return to Azatlan: The Social Process of International Migration from Western Mexico. Oakland, CA: University of California Press.

Massey, D., and K. Espinosa. 1997. "What's Driving Mexico-U.S. Migration? A Theoretical, Empirical, and Policy Analysis." American Journal of Sociology 102 (4): 939-99.

Massey, D. S., M. J. Fischer, and C. Capoferro. 2006. "International Migration and Gender in Latin America: A Comparative Analysis." International Migration 44 (5): 63-9l.

Mendola, M. (2008). Migration and technological change in rural households: Complements or 
substitutes?. Journal of Development Economics, 85(I), I50-175.

McCormick Barry and JacklineWahba. (200I). Overseas Work Experience, Savings and Entrepreneurship Amongst Return Migrants to LDCs. Scottish Journal of Political Economy, 48, 164- 178.

McKenzie, D. J., \&Rapoport, H. (2006). Migration and education inequality in rural Mexico (Working Paper ITD= Documento de Trabajo ITD; $n$. 23) (Vol. 23). BID-INTAL.

McKenzie D and Sasin M.J. (2007). Migration, Remittances, Poverty, and Human Capital: Conceptual and Empirical Challenges. World Bank Policy Research Working Paper No. 4272.

Michel Beine\&FrédericDocquier\& Hillel Rapoport. (2008). Brain Drain and Human Capital Formation in Developing Countries: Winners and Losers. Economic Journal, I I8(528), 63I-652.

Michel Beine\&FrédéricDocquier\& Hillel Rapoport. (20/3). Michel BeinBrain drain and human capital formation in developing countries: winners and losers? ULB Institutional Repository 20/3/I04/5.

Miro Carmen A. and Joseph E. Potter. (1980). Population Policy: Research Priorities in the developing World. London: FRances Pinter (Publishers).

Mora, J., \& Taylor, J. E. (2006). Does migration reshape expenditures in rural households? Evidence from Mexico. Evidence from Mexico Asia." Southeast Asian Workers Remittance Study, Asian Development Bank, Manila.

Orozco, G., Sánchez, E., González-Gay, M. A., López-Nevot, M. A., Torres, B., Cáliz, R., ...\& de Pablo, R. (2005). Association of a functional single-nucleotide polymorphism of PTPN22, encoding lymphoid protein phosphatase, with rheumatoid arthritis and systemic lupus erythematosus.Arthritis\& Rheumatism, 52(I), 219-224.

Orozco, M.. 2007. "Migrant Foreign Savings and Asset Accumulation." In Reducing Global Poverty. The Casefor Asset Accumulation, edited by C. Moser. Washington, DC: Brookings Institution Press.

Oucho John O. (2006). Migration and refugees in Eastern Africa: A challenge for the East African Community." In Views on Migration in SubSaharan Africa. (D. G. Catherine Cross, Ed.) HSRC Press.

OzdenCaglar\& Schiff Maurice Niimi Yoko. (2008). Remittances and the Brain Drain: Skilled Migrants Do Remit Less. IZA Discussion Papers 3393.

Rogaly B., Coppard D.,Rafique A. ,Rana K. Sengupta A. and Biswas J. (2003). Seasonal Migration,
(February I, 2006). World Bank Policy Research Working Paper, (3842).

Msigwa, R. E., \&Mbongo, J. E. (20/3).Determinants of internal migration in Tanzania. Journal of Economics and Sustainable Development, 4(9), 28-35.

Munshi, K. (2003). Networks in the Modern Economy: Mexican Migrants in the US Labor Market. Quarterly Journal of Economics, No. / /8, 549-599.

Musumba $M$ and Mjelde J. (2013). Remitter/Receiver Relations in Africa.Agricultural and Applied Economics Association.

Nyberg-Sorensen Van Hear $\mathrm{N}$ and Engberg-Pedersen P. (2002). The migration - development Nexus: evidence and policy options; state of the art overview. International Migration, 40(5), 3-48.

Omondi OC, Ayiemba EHO. Fertility differentials in Kenya: the effect of female migration. Afr Popul Stud. 2005; 20(2):25-42.

Orozco M Bump Micah Fedewa R and Sienkiewicz K. (2005).Diaspora, Development and Transnational Integration: Ghanaians in US, UK and Germany.Citizenship International through USAID.

Orozco $M$ Lowell BL Bump $M$ and Fedewa $R$. (2005).Transnational engagement, remittances and their relationship to development in Latin America and the Caribbean.

Orozco, M. 2005. "Regional Integration: Trends and Patterns of Remittance Flows within Southeas

Rafique A \&Rogaly B. (2003).Internal Seasonal Migration, Livelihoods and Vulnerability in India: A Case Study'. DFID-RMMRU Conference on Migration Development and Pro -poor Policy Choices in Asia.Dhaka.

Ratha D and Mohapatra S. (2007).Increasing the Macroeconomic impact of remittances on development.Development Prospects group.

Ratha, D. (2006). Trends, Determinants and Macroeconomic Effects of Remittances.Global Economic Prospects 2006: Economic Implications of Remittances and Migration.

Ravallion M and Wodon Q. (1999). Poor areas, or only poor people? journal of regional science, 30(4), 689-7I 2.

Rocher Pelletier. (2008). Migrant workers' remittances: what is the impact on the economic and financial development of Sub-Saharan African countries?(Vol. 13). Paris: Banque de France bulletin.

Rodriguez, E. (1996). International Migrants, Remittances in the Philipines. The Canadian Journal of Economics, 29, 427-432.

Employer-Worker interactions, and Shifting ethnic identities in Contemporary West 
Bengal.Contributions to Indian Sociology, 37(I\&2), 28I-3I0.

Rogaly B. Coppard D. Rafique A. Rana K. , and Sengupta A. (2002). Seasonal Migration and Welfare/llffare in Eastern India: A Social Analysis. Journal of Development Studies, 38(5), 89-I I 4.

Uganda Bureau of Statistics 2016, The National Population and Housing Census 2014 - Main Report, Kampala, Uganda

World Bank (2006).Economic Implications of.Remittances and Migration.World Bank's Global Economic Prospects.

World Bank.(2007). World Development Indicators.Migration and Remittance fact book. Retrieved www.worldbank.org/prospects/migrationandremi $\underline{\text { ttances }}$

World Bank. (2009). Reshaping Economic Geography. Retrieved from world development report: www- World Bank. (20II). The Changing Wealth of Nations : Measuring Sustainable Development in the New Millennium. World Bank Publications(2252).

World Bank Global Economic Prospects.(2006). Economic Implications and Migration.World Bank. Yang, D. (2004).International Migration, Human Capital and Entrepreneurship: Evidence from Philippine Migrants' Exchange Rate Shocks. Ann Arbor, MI, USA: University of Michigan.Yang, D.(2006) 